\title{
DETERMINAN KUALITAS LAPORAN KEUANGAN PEMERINTAH DAERAH: STUDI PADA OPD PEMERINTAH KOTA PEKANBARU
}

\author{
Justika Zebua ${ }^{1}$, Muhammad Rasuli ${ }^{2}$, Vera Oktari ${ }^{\mathbf{3}^{*}}$ \\ ${ }^{123}$ Program Studi Akuntansi, Fakultas Ekonomi dan Bisnis, Universitas Riau, Pekanbaru \\ *E-mail: vera.oktari@lecturer.unri.ac.id
}

\begin{tabular}{l} 
Keywords \\
\hline Human Resources \\
Competencies, \\
Utilization of \\
Information \\
Technology, The \\
Application of Internal \\
Control System, The \\
Quality of Financial \\
Reports
\end{tabular}

\begin{tabular}{l} 
Article Information \\
\hline Received: \\
2020-05-11 \\
Accepted: \\
2020-06-07 \\
Available online: \\
2020-07-18
\end{tabular}

\begin{abstract}
This study aims to explain how Human Resources Competencies, Utilization of Information Technology and The Application of Internal Control System determine of the Quality of Financial Reports of Pekanbaru City. This study uses a quantitative method. The population in this study were 33 OPD in Pekanbaru City Government. The sample determination technique uses a purposive sampling method, where questionnaires distributed to 99 respondents were determined to the Head of Department, Head of Division/SubDivision/Financial Staff and PPTK of each OPD. The hypothesis test used in this study uses t-Test. The statistical test aids used in this study were the SPSS program ver. 20 for Windows and Ms. Excel 2013. The results show that the Competencies of Human Resources, Utilization of Information Technology and the Application of Internal Control System partially affected the Quality of Local Government Financial Reports.
\end{abstract}

\section{PENDAHULUAN}

Perubahan sistem penyelenggaraan pemerintah daerah dari sentralisasi ke desentralisasi membuat berlakunya otonomi daerah. Otonomi daerah sebagaimana dimaksud dalam Undang-Undang No. 9 Tahun 2015 adalah hak, wewenang, dan kewajiban daerah otonom untuk mengatur dan mengurus sendiri urusan pemerintahan dan kepentingan setempat sesuai dengan perundang-undangan. Berlakunya otonomi daerah membuat pemerintah daerah dapat mengelola keuangan daerah sepenuhnya.

Berdasarkan Peraturan Pemerintah No. 12 Tahun 2019 tentang Pengelolaan Keuangan Daerah adalah seluruh kegiatan yang terdiri dari perencanaan, penganggaran, pelaksanaan, penatausahaan, pelaporan, pertanggungjawaban, dan pengawasan keuangan daerah. Pelaksanaan pengelolaan keuangan daerah diharuskan tertib, akuntabel dan transparan guna 
terwujudnya pemerintahan yang bersih. Bentuk pertanggungjawaban dalam penyelenggaraan pemerintahan daerah adalah dengan mengadakan pelaporan keuangan sebagaimana diatur dalam Undang Undang No. 17 Tahun 2003 tentang Keuangan Negara dan Undang Undang No. 9 Tahun 2015 tentang Pemerintahan Daerah, sebagai tindakan untuk mewujudkan transparansi dan akuntabilitas pengelolaan keuangan daerah. Laporan keuangan yang dihasilkan harus sesuai dengan Peraturan Pemerintah No. 71 Tahun 2010 tentang Standar Akuntansi Pemerintahan.

Laporan keuangan pemerintah adalah struktur yang menyajikan posisi keuangan dan kinerja keuangan dalam sebuah entitas (IAI, 2015:2). Laporan keuangan pemerintah daerah bertujuan untuk mempertanggungjawabkan pelaksanaan fungsi laporan keuangan, melaporkan hasil operasi, melaporkan kondisi keuangan dan melaporkan sumber daya jangka panjang (GASB, 2009:54). Berdasarkan tujuan tersebut, diharapkan laporan keuangan pemerintah daerah memiliki kualitas.

Laporan keuangan yang berkualitas didasari oleh teori keagenan, yaitu suatu kontrak antara pengelola (agent) yaitu pemerintah dan publik (principal) yaitu rakyat yang diwakili dewan, dimana agen melakukan suatu jasa atas nama prinsipal serta memberi wewenang kepada agen untuk membuat keputusan yang terbaik bagi prinsipal (Jensen dan Meckling, 1976 dan Lane, 2003). Maksudnya adalah pemerintah daerah sebagai agen bertugas untuk memberikan jasa, dalam hal ini pengelolaan keuangan daerah yang akuntabel, yang dilakukan atas kepentingan publik yang diwakilkan oleh DPRD sebagai wakil rakyat. Pemerintah daerah merupakan agen bagi DPRD dan publik/rakyat (dual accountability) dan DPRD menjadi agen bagi publik. Intinya adalah pertanggungjawaban laporan keuangan dilakukan atas nama rakyat dan untuk kepentingan rakyat.

Kualitas laporan keuangan adalah ukuran atau taraf seberapa mampu informasi laporan keuangan pemerintah daerah memenuhi karakteristik kualitatif informasi keuangan yang disyaratkan dalam pengungkapan secara penuh dan wajar. Kualitas Laporan Keuangan Pemerintah Daerah (LKPD) penting, sebab membantu pengguna dalam memenuhi kebutuhannya atas informasi keuangan sekaligus memberikan perlindungan kepada pemilik berdasarkan karakteristik kualitatif informasi keuangan dan pengungkapan secara penuh dan wajar menjadi salah satu bentuk tata kelola pemerintahan yang baik (Yadiati, 2017).

BPK setiap tahun memberikan penilaian berupa opini terhadap LKPD, yang mana opini tersebut menjadi salah satu indikator penilaian kualitas laporan keuangan. Terdapat jenjang penilaian laporan keuangan dari hasil pemeriksaan berupa enam jenis opini sesuai dengan Peraturan BPK No. 1 Tahun 2017, yaitu Opini Wajar Tanpa Pengecualian (WTP), 
Wajar Tanpa Pengecualian Dengan Paragraf Penekanan Suatu Hal, Wajar Dengan Pengecualian (WDP) karena pembatasan ruang lingkup, Wajar Dengan Pengecualian (WDP) karena adanya penyimpangan standar akuntansi, Opini Tidak Wajar (TP), dan Tidak Memberi Pendapat (TMP).

LKPD yang mendapat opini WTP menandakan secara umum tata kelola keuangannya sudah baik. Pemberian opini WTP berdasarkan empat kriteria, yaitu kepatuhan pengelolaan keuangan/aset terhadap peraturan perundang-undangan, efektifitas pelaksanaan sistem pengendalian intern, kesesuaian dengan SAP dan pengungkapan informasi dalam LKPD yang lengkap atau memadai. Namun, bukan berarti LKPD yang mendapatkan WTP bebas dari kesalahan dan kelemahan (Treasury Indonesia, 2017).

Peraturan Pemerintah No. 71 Tahun 2010 tentang Standar Akuntansi Pemerintahan bagian Kerangka Konseptual Akuntansi Pemerintahan memuat kriteria dan unsur yang membentuk kualitas laporan keuangan, yaitu: 1) Relevan, 2) Andal, 3) Dapat dibandingkan dan 4) Dapat dipahami.

LKPD Tahun 2018 Kota Pekanbaru mendapat opini WTP, pada Sidang Paripurna Istimewa DPRD Riau. Pemerintah Kota Pekanbaru telah mendapat opini WTP sebanyak 3 kali berturut-turut terhitung sejak tahun pelaporan 2016-2018 (Ikhtisar Hasil Pemeriksaan BPK atas LKPD Tahun 2016-2018).

Konsistensi Pemerintah Kota Pekanbaru dalam mempertahankan kualitas laporan keuangannya merupakan suatu topik yang menarik untuk diteliti. Walau sudah tiga kali mendapat opini WTP, laporan keuangan pemerintah Kota Pekanbaru masih terdapat temuan pemeriksaan. Adapun temuan tersebut berasal dari kelemahan sistem pengendalian intern dan terkait dengan ketidakpatuhan terhadap perundang-undangan dalam penyusunan laporan keuangan. Selain itu, pada awal tahun 2019 lalu terdapat 9 OPD di Pemerintah Kota Pekanbaru yang tak kunjung menyelesaikan laporan keuangan tahun 2018. Deadline diberikan pemko Pekanbaru sampai tanggal 19 Maret 2019 belum optimal, sehingga diberikan waktu lebih kepada OPD yang harus menggesa pelaporan keuangannya. Artinya, penyusunan laporan keuangan sebagian OPD di Pemko Pekanbaru masih tidak tepat waktu, yang mana belum memenuhi karakteristik kualitatif yang disyaratkan; yaitu relevan (www.cakaplah.com).

Berdasarkan fenomena-fenomena di atas, dapat dinyatakan bahwa LKPD Kota Pekanbaru masih perlu dilakukan pembenahan terhadap berbagai aspek pada pemerintah daerah terutama bagian penatausahaan keuangan agar hasil dari laporan keuangan yang diterbitkan berkualitas serta bernilai informasi yang akurat.

OPD sebagai organisasi pemerintahan daerah membutuhkan sumber daya manusia 
yang kompeten. Pengetahuan dan keterampilan di bidang akuntansi dibutuhkan untuk dapat mengelola informasi akuntansi. Menurut Juita (2013) dalam Karsana dan Suaryana (2017), sumber daya manusia merupakan unsur yang sangat penting dalam organisasi, karena sumber daya manusia ini dipastikan terlatih dengan baik agar kontribusi yang diberikan maksimal dalam pencapaian tujuan organisasi. Oleh karena itu, kompetensi sumber daya manusia diperlukan dalam mengelola dan menyajikan informasi keuangan sehingga laporan keuangan yang disusun berkualitas. Hal ini sependapat dengan penelitian yang dilakukan oleh Indriasih (2014), Tawaqal dan Suparno (2017), Evicahyani dan Setiawina (2016), Karsana dan Suaryana (2017) serta Oktavia dan Rahayu (2019) mengatakan bahwa kompetensi sumber daya manusia memiliki pengaruh positif terhadap kualitas LKPD. Namun, dalam penelitian Sholohah dan Sulistyawati (2018) membantah pernyataan tersebut.

Pemanfaatan teknologi informasi dalam manajemen data keuangan memberikan keakuratan dan fleksibilitas dalam penyusunan laporan keuangan. Laporan keuangan dapat disajikan tepat waktu karena teknologi informasi mendukung percepatan pemrosesan data transaksi. Sehingga laporan keuangan dapat siap tepat waktu dan tidak kehilangan kualitasnya (Wardani dan Nugroho, 2018). Salah satu bentuk pemanfaatan teknologi informasi dalam bidang keuangan adalah penerapan Sistem Akuntansi Keuangan Daerah (SAKD) sesuai SAP yang bertujuan menggalakkan akuntabilitas dan keandalan pengelolaan keuangan pemerintah daerah melalui penataan dan pengembangan SAP berbasis akrual dalam menyusun LKPD. Hal ini sejalan dengan penelitian yang telah dilakukan oleh Tawaqal dan Suparno (2017), Wardani dan Nugroho (2018), Oktavia dan Rahayu (2019) serta Hasanah, dkk. (2019) mengatakan bahwa pemanfaatan teknologi informasi memiliki pengaruh positif terhadap kualitas LKPD. Namun, dibantah oleh penelitian Sholohah dan Sulistyawati (2018).

LKPD harus disusun berdasarkan Sistem Pengendalian Intern seperti yang tertera dalam Pasal 56 Ayat (4) Undang-Undang No. 01 Tahun 2004 tentang Perbendaharaan Negara yang menyebutkan bahwa kepala OPD selaku pengguna anggaran/barang memberikan pernyataan bahwa pengelolaan APBD di lingkungan kerjanya telah menyelenggarakan Sistem Pengendalian Intern secara memadai dan menyusun laporan keuangan sesuai dengan SAP. Tingkat SPI pada OPD Kota Pekanbaru masih dalam level 2 (berkembang) menuju level 3 (terdefinisi), artinya pemda Pekanbaru telah melaksanakan praktik pengendalian intern, namun tidak terdokumentasi dengan baik dan pelaksanaannya sangat tergantung pada individu dan belum melibatkan semua unit organisasi, sehingga masih terdapat kelemahan yang cukup berarti (BPKP, 2018). Hal ini searah dengan penelitian yang telah dilakukan oleh Indriasih (2014), Herawati (2014), Karsana dan Suaryana (2017) dan Muhammad (2019) yang 
mengatakan bahwa penerapan sistem pengendalian intern memiliki pengaruh positif terhadap kualitas LKPD. Sebaliknya, pernyataan tersebut dibantah oleh Wawo, dkk. (2013).

Ketidakkonsistenan hasil di atas menyebabkan Peneliti ingin meneliti kembali determinan kualitas laporan keuangan pemerintah daerah. Penelitian ini merupakan pengembangan dari penelitian Tawaqal dan Suparno (2017). Perbedaannya terletak pada: pertama, variabel independen penerapan sistem informasi akuntansi tidak digunakan, yang mana dalam penelitian ini menggunakan variabel independen pemanfaatan teknologi informasi. Kedua, penelitian tersebut dilakukan di OPD Pemerintah Kota Banda Aceh, sedangkan penelitian ini dilakukan di OPD Pemerintah Kota Pekanbaru.

Berdasarkan latar belakang masalah di atas, membuat peneliti ingin mengetahui pengaruh sebenarnya dari variabel-variabel independen tersebut terhadap kualitas laporan keuangan pemerintah daerah.

\section{PENGEMBANGAN HIPOTESIS}

Pengaruh Kompetensi Sumber Daya Manusia terhadap Kualitas Laporan Keuangan Pemerintah Daerah

Kompetensi sumber daya manusia adalah kemampuan yang dimiliki seseorang pegawai yang bersangkutan dengan pengetahuan, keterampilan dan sikap yang secara langsung dapat mempengaruhi kinerjanya dalam upaya mencapai tujuan yang diinginkan. Kompetensi sumber daya manusia sangat diperlukan agar laporan keuangan yang dihasilkan dapat memenuhi karakteristik kualitatif laporan keuangan. Keberhasilan suatu entitas dipengaruhi oleh kompetensi sumber daya manusia yang dimiliki untuk merumuskan, melaksanakan, dan mengendalikan entitas tersebut. Sumber daya manusia yang akan menjalankan sistem atau yang menghasilkan informasi tersebut, dituntut untuk memiliki tingkat keahlian akuntansi yang memadai dan atau paling tidak memiliki keinginan untuk terus belajar dan mengasah kemampuannya di bidang akuntansi. Apabila pegawai, khususnya yang berhubungan dengan penyusunan laporan keuangan dari suatu organisasi ataupun instansi tidak berkompeten, dalam arti mengerti akuntansi, maka kualitas dari laporan keuangan daerah yang dikeluarkan akan mengalami penurunan atau kurang berkualitas. Namun sebaliknya, apabila pegawai dari suatu organisasi atau instansi itu berkompeten, maka laporan keuangan daerah yang dikeluarkan akan baik atau berkualitas.

Hasil penelitian ini didukung oleh penelitian yang dilakukan oleh Evicahyani dan Setiawina (2016), Oktavia dan Rahayu (2019), Karsana dan Suaryana (2017), Tawaqal dan Suparno (2017) serta Indriasih (2014) yang menunjukkan bahwa kompetensi sumber daya 
DETERMINAN KUALITAS LAPORAN KEUANGAN PEMERINTAH DAERAH: STUDI PADA OPD PEMERINTAH KOTA

manusia berpengaruh positif terhadap kualitas laporan keuangan daerah. Berdasarkan uraian tersebut, maka dirumuskan hipotesis:

$\mathrm{H}_{1}$ : Kompetensi Sumber Daya Manusia berpengaruh signifikan terhadap Kualitas Laporan Keuangan Pemerintah Daerah.

\section{Pengaruh Pemanfaatan Teknologi Informasi Terhadap Kualitas Laporan Keuangan Pemerintah Daerah}

Peraturan Pemerintah No. 56 Tahun 2005 tentang Sistem Informasi Keuangan Daerah menyebutkan bahwa untuk meneruskan terselenggaranya proses pembangunan yang sesuai dengan prinsip tata kelola pemerintahan yang baik, pemerintah, serta pemerintah daerah wajib mengembangkan dan memanfaatkan kemajuan teknologi informasi guna meningkatkan kemampuan pengelolaan keuangan daerah, dan mendistribusikan informasi keuangan daerah kepada pelayanan publik. Pemanfaatan kemajuan teknologi informasi perlu dioptimalisasikan pemerintah daerah untuk membangun jaringan sistem informasi manajemen dan proses kerja yang memungkinkan pemerintahan bekerja secara terpadu dengan menyederhanakan akses antar unit kerja.

Salah satu bentuk dari pemanfaatan teknologi informasi dalam hal penyusunan laporan keuangan adalah penerapan sistem akuntansi keuangan daerah. Dalam Permendagri No. 59 Tahun 2007, Sistem Akuntansi Keuangan Daerah (SAKD) adalah serangkaian tahapan yang dimulai dari proses pengumpulan data, pencatatan, pengikhtisaran, sampai pelaporan keuangan dalam rangka pertanggungjawaban pelaksanaan APBD yang dilakukan secara manual atau secara terkomputerisasi.

Hal ini didukung oleh penelitian yang dilakukan oleh Tawaqal dan Suparno (2017), Wardani dan Nugroho (2018), Oktavia dan Rahayu (2019) serta Hasanah, dkk. (2019) yang menyebutkan bahwa pemanfaatan teknologi informasi berpengaruh positif terhadap kualitas laporan keuangan daerah. Berdasarkan uraian tersebut, maka dirumuskan hipotesis:

$\mathbf{H}_{2}$ : Pemanfaatan Teknologi Informasi berpengaruh signifikan terhadap Kualitas Laporan Keuangan Pemerintah Daerah.

\section{Pengaruh Penerapan Sistem Pengendalian Intern terhadap Kualitas Laporan Keuangan Pemerintah Daerah}

Weygandt et all (2005) mengungkapkan bahwa, jika pengendalian internal telah diterapkan maka tiap kegiatan, sumber daya dan data akan dapat dipantau, diawasi, 
tercapainya tujuan, kecilnya risiko, dan menghasilkan informasi yang berkualitas. Dengan menerapkan pengendalian internal dalam sistem akuntansi, maka informasi akuntansi yang dihasilkan akan lebih berkualitas (relevan, akurat, tepat waktu, dan lengkap), serta dapat diaudit (Herawati, 2014).

Keefektifan penyelenggaraan pengendalian intern dapat dilihat dari tingkat maturitasnya. Tingkat maturitas penyelenggaraan SPIP adalah tingkat kematangan/kesempurnaan penyelenggaraan sistem pengendalian intern pemerintah dalam mencapai tujuan pengendalian intern sesuai dengan Peraturan Pemerintah No. 60 Tahun 2008 tentang Sistem Pengendalian Intern Pemerintah. Tingkat maturitas SPIP terdiri dari level 0 sampai level 5. Semakin tinggi tingkat maturitas SPIP pada suatu Kementerian/Lembaga/Pemda, maka pengendalian internalnya sudah dilakukan dengan baik dan berkelanjutan, terintegarasi dalam pelaksanaan kegiatan yang didukung oleh pemantauan otomatis menggunakan aplikasi komputer, sehingga meminimalkan kesalahsajian laporan keuangan. Begitu juga sebaliknya, jika tingkat maturitas SPIP pada suatu Kementerian/Lembaga/Pemda rendah, maka pengendalian internalnya buruk, sehingga laporan keuangan yang dihasilkan tidak berkualitas.

Herawati (2014), Indriasih (2014), Muhammad (2019) Karsana dan Suaryana (2017) serta Tawaqal dan Suparno (2017) membuktikan secara empiris bahwa sistem pengendalian internal akuntansi berpengaruh positif terhadap kualitas laporan keuangan pemerintah daerah yang dinyatakan dengan ketepatwaktuan dan keterandalan. Berdasarkan uraian tersebut, maka dapat dirumuskan hipotesis:

\section{$\mathrm{H}_{3}$ : Penerapan Sistem Pengendalian Intern berpengaruh signifikan terhadap Kualitas Laporan Keuangan Pemerintah Daerah.}

\section{METODE PENELITIAN}

\section{Populasi dan Sampel}

Populasi dalam penelitian ini adalah seluruh Organisasi Perangkat Daerah di Pemerintah Kota Pekanbaru. Sampel dalam penelitian ini ditentukan dengan metode purposive sampling, yang mana kriteria sampel ditentukan atas dasar bahwa sampel tersebut merupakan pihak yang terlibat secara langsung dalam rekapitulasi transaksi keuangan OPD dan penyusunan laporan keuangan pemerintah daerah. Sampel dalam penelitian ini sebanyak 99 responden dari 33 OPD, yang terdiri dari Kepala Dinas masing-masing OPD, Kepala Bagian/Sub Bagian/Staf Keuangan masing-masing OPD, Pejabat Pelaksana Teknis Kegiatan masing-masing OPD. 
Penentuan responden didasarkan pada alasan; (a) Membuat unit analisis bersifat heterogen dan respon dari responden dapat tersebar merata di masing-masing OPD, (b) Diasumsikan bahwa 3 responden ini pasti mengetahui tentang pelaporan keuangan pada masing-masing OPD.

\section{Teknik Pengumpulan Data}

Teknik pengumpulan data yang digunakan dalam penelitian ini menggunakan kuesioner yang pernyataan-pernyataannya dibagi menjadi beberapa bagian dan merupakan kumpulan dari beberapa penelitian terdahulu.

\section{Definisi Operasional dan Pengukuran Variabel}

Berikut adalah operasionalisasi variabel yang diukur menggunakan Skala Likert dengan skor 5 poin, mulai dari poin 1 sangat tidak setuju sampai poin 5 sangat setuju, yang menghasilkan data ordinal.

\section{Tabel 1}

\section{Instrumen Penelitian}

\begin{tabular}{|c|c|c|c|}
\hline No & Variabel & Indikator & Skala \\
\hline \multirow[t]{4}{*}{1} & Kualitas Laporan & 1. Relevan & Likert \\
\hline & Keuangan Pemerintah & 2. Andal & \\
\hline & Daerah & 3. Dapat dibandingkan & \\
\hline & & 4. Dapat dipahami & \\
\hline \multirow[t]{3}{*}{2} & Kompetensi Sumber Daya & 1. Pengetahuan & Likert \\
\hline & Manusia & 2. Keahlian & \\
\hline & & 3. Perilaku & \\
\hline \multirow[t]{8}{*}{3} & Pemanfaatan Teknologi & 1. Memiliki komputer & Likert \\
\hline & Informasi & 2. Jaringan internet & \\
\hline & & 3. Jaringan internet termanfaatkan dengan baik & \\
\hline & & 4. Sistem terkomputerisasi & \\
\hline & & 5. Software sesuai dengan UU & \\
\hline & & 6. Integritas & \\
\hline & & 7. Pemilihan peralatan & \\
\hline & & 8. Perbaikan peralatan & \\
\hline \multirow[t]{5}{*}{4} & Sistem Pengendalian & 1. Lingkungan pengendalian & Likert \\
\hline & Intern & 2. Penilaian risiko & \\
\hline & & 3. Kegiatan pengendalian & \\
\hline & & 4. Informasi dan komunikasi & \\
\hline & & 5. Pemantauan & \\
\hline
\end{tabular}

Sumber: Penelitian Terdahulu

\section{Metode Analisis Data}

Hipotesis dalam penelitian ini diuji dengan menggunakan uji t yang menggunakan alat bantu uji statistik program SPSS ver. 20 for Windows dan Microsoft Excel 2013 yang termasuk dalam uji analisis linear berganda. Model uji analisis linear berganda adalah sebagai berikut: 


$$
\mathrm{Y}=\quad \alpha+\beta_{1} x_{1}+\beta_{2} x_{2}+\beta_{3} x_{3}+e
$$

Keterangan:

$$
\begin{aligned}
& Y=\text { Kualitas Laporan Keuangan } \\
& \alpha=\text { Konstanta } \\
& \beta 1=\text { koefisien regresi Kompetensi Sumber Daya Manusia } \\
& \beta 2=\text { koefisien regresi Pemanfaatan Teknologi Informasi } \\
& \beta 3=\text { koefisien regresi Sistem Pengendalian Intern } \\
& X 1=\text { variabel Kompetensi Sumber Daya Manusia } \\
& X 2=\text { variabel Pemanfaatan Teknologi Informasi } \\
& X 3=\text { variabel Sistem Pengendalian Intern } \\
& \text { e }=\text { variabel pengganggu }
\end{aligned}
$$

\section{HASIL PENELITIAN DAN PEMBAHASAN}

\section{Hasil Uji Statistik Deskriptif}

Tabel berikut menampilkan hasil uji statistik deskriptif berdasarkan data yang diperoleh dari pengisian kuesioner oleh responden.

\section{Tabel 2}

\section{Hasil Uji Statistik Deskriptif}

\begin{tabular}{lccccc}
\hline & N & Min & Max & Mean & Std. Deviation \\
\hline Kompetensi Sumber Daya Manusia (X1) & 83 & 20 & 29 & 24,75 & 2,053 \\
Pemanfaatan Teknologi Informasi (X2) & 83 & 29 & 40 & 33,14 & 2,159 \\
Sistem Pengendalian Intern (X3) & 83 & 31 & 42 & 37,29 & 2,156 \\
Kualitas Laporan Keuangan Pemerintah Daerah (Y) & 83 & 31 & 39 & 33,96 & 2,039 \\
Valid N (listwise) & 83 & & & & \\
\hline Sumbers
\end{tabular}

Sumber: Olah data dengan menggunakan SPSS

Dari data di atas, dapat dilihat Kompetensi Sumber Daya Manusia (X1) dengan nilai minimum 20, nilai maksimum 29, nilai rata-rata 24,75 dengan standar deviasi 2,053. Pemanfaatan Teknologi Informasi (X2) dengan nilai minimum sebesar 29, nilai maksimum 40 dan nilai rata-rata sebesar 33,14 dengan standar deviasi sebesar 2,159. Sistem Pengendalian Intern (X3) dengan nilai minimum sebesar 31, nilai maksimum 42 dan nilai rata-rata sebesar 37,29 dengan standar deviasi sebesar 2,156. Kualitas Laporan Keuangan Pemerintah Daerah (Y) dengan nilai minimum sebesar 31, nilai maksimum 39 dan nilai rata-rata sebesar 33,96 dengan standar deviasi sebesar 2,039. Nilai rata-rata dan nilai standar deviasi setiap variabel menunjukkan bahwa terdapat penyebaran data yang baik karena nilai rata-ratanya lebih besar dari pada standar deviasinya. Artinya, data yang telah dikumpulkan dan dianalisis dapat 
DETERMINAN KUALITAS LAPORAN KEUANGAN PEMERINTAH DAERAH: STUDI PADA OPD PEMERINTAH KOTA PEKANBARU

menggambarkan nilai variabel dependen dan variabel independen dengan akurat.

\section{Hasil Uji Analisis Regresi Linear Berganda}

Berikut ini adalah hasil pengujian analisis regresi linear berganda dengan menggunakan SPSS untuk pengujian seluruh hipotesis.

\section{Tabel 3}

\section{Hasil Uji Analisis Regresi Linear Berganda}

\begin{tabular}{|c|c|c|c|c|c|}
\hline \multirow[b]{3}{*}{ Model } & \multicolumn{5}{|c|}{ Coefficients $^{\mathrm{a}}$} \\
\hline & \multicolumn{2}{|c|}{$\begin{array}{l}\text { Unstandardized } \\
\text { Coefficients }\end{array}$} & \multirow{2}{*}{$\begin{array}{c}\begin{array}{c}\text { Standardized } \\
\text { Coefficients }\end{array} \\
\text { Beta }\end{array}$} & \multirow[t]{2}{*}{$\mathbf{t}$} & \multirow[t]{2}{*}{ Sig. } \\
\hline & B & Std. Error & & & \\
\hline $1 \quad$ (constant) & 7,261 & 3,055 & & 2,377 &, 020 \\
\hline Kompetensi Sumber Daya (X1) & 287 & ,096 & 289 & 2,982 & 004 \\
\hline Pemanfaatan Teknologi Informasi & & & & & \\
\hline (X2) & 263 & ,088 & 279 & 2,990 & ,004 \\
\hline Sistem Pengendalian Intern (X3) & 291 & ,094 & ,308 & 3,090 & ,003 \\
\hline a Dependent Variable: Kualitas Lapo & Keuan & in Pemerintal & Daerah (Y) & & \\
\hline
\end{tabular}

Sumber: Olah data dengan menggunakan SPSS

Berdasarkan hasil uji di atas, dapat disimpulkan bahwa seluruh variabel independen dalam penelitian ini berpengaruh positif terhadap variabel dependen. Diketahui dari masingmasing nilai Beta variabel dependen yang jika dibulatkan menjadi 1 satuan, maka dapat meningkatkan variabel Kualitas Laporan Keuangan Pemerintah Daerah sebesar nilai B masing-masing variabel dependen, dengan asumsi variabel lain tetap.

\section{Pengaruh Kompetensi Sumber Daya Manusia terhadap Kualitas Laporan Keuangan Pemerintah Daerah}

Berdasarkan uji parsial t pada hipotesis pertama, telah didapat nilai t tabel adalah 1,994, thitung adalah 2,982 dan signifikansinya 0,004 . Ketentuan dari uji parsial t ini adalah jika $\mathrm{t}$ hitung $<\mathrm{t}$ tabel maka $\mathrm{H}_{1}$ diterima dan $\mathrm{Ha}_{1}$ ditolak begitu juga sebaliknya. Jika $\mathrm{H} 0_{1}$ ditolak dan $\mathrm{Ha}_{1}$ diterima, maka nilai signifikansinya harus $<0,05$. Dari hasil uji t hipotesis pertama didapat $\mathrm{t}$ hitung $>\mathrm{t}$ tabel yaitu $2,982>1,994$ dengan nilai sig.t $0,004<0,05$. Dari keterangan tersebut, ditarik kesimpulan bahwa hasil dari uji t hipotesis pertama adalah Kompetensi Sumber Daya Manusia berpengaruh signifikan terhadap Kualitas Laporan Keuangan Pemerintah Daerah.

Berdasarkan data yang diperoleh dalam penelitian, diketahui sumber daya manusia bagian keuangan di tiap OPD Pemerintah Kota Pekanbaru sudah baik. Berdasarkan hasil analisis dan pengujian yang dilakukan, menunjukkan bahwa semakin kompeten sumber daya manusia yang dimiliki maka semakin berkualitas laporan keuangan yang dihasilkan. 
Hubungan antara kompetensi sumber daya manusia dan kualitas laporan keuangan dapat dijelaskan oleh Teori Keagenan. Teori ini menjelaskan bahwa pemerintah daerah sebagai agent diwajibkan memenuhi kebutuhan rakyat sebagai principal yang diwakilkan oleh DPRD dalam menghasilkan laporan keuangan yang berkualitas dan akuntabel agar memudahkan principal dalam mengambil keputusan. Sumber daya yang kompeten akan memudahkan pemerintah daerah untuk menghasilkan laporan keuangan yang berkualitas. Penelitian ini mendukung penelitian Indriasih (2014), Karsana dan Suaryana (2017), Tawaqal dan Suparno (2017), Evicahyani dan Setiawina (2016), serta Oktavia dan Rahayu (2019).

\section{Pengaruh Pemanfaatan Teknologi Informasi Terhadap Kualitas Laporan Keuangan Pemerintah Daerah}

Berdasarkan uji parsial t pada hipotesis kedua, telah didapat nilai t tabel adalah 1,994, $\mathrm{t}$ hitung adalah 2,990 dan signifikansinya 0,004. Ketentuan dari uji parsial $\mathrm{t}$ ini adalah jika $\mathrm{t}$ hitung $<\mathrm{t}$ tabel maka $\mathrm{H}_{2}$ diterima dan $\mathrm{Ha}_{2}$ ditolak begitu juga sebaliknya, Jika $\mathrm{H}_{2}$ ditolak dan $\mathrm{Ha}_{2}$ diterima, maka nilai signifikansinya harus $<0,05$. Dari hasil uji t hipotesis kedua didapat $\mathrm{t}$ hitung $>\mathrm{t}$ tabel yaitu 2,990 $>1,994$ dengan nilai sig.t $0,004<0,05$. Dari keterangan tersebut, ditarik kesimpulan bahwa hasil dari uji t hipotesis kedua adalah Pemanfaatan Teknologi Informasi berpengaruh signifikan terhadap Kualitas Laporan Keuangan Pemerintah Daerah.

Berdasarkan data yang diperoleh, diketahui pemanfaatan teknologi informasi bagian keuangan di tiap OPD Pemerintah Kota Pekanbaru dikatakan baik. Berdasarkan hasil analisis dan pengujian yang dilakukan, menunjukkan bahwa semakin efisien teknologi informasi yang digunakan maka semakin berkualitas laporan keuangan yang dihasilkan. Hubungan antara pemanfaatan teknologi informasi dan kualitas laporan keuangan dapat dijelaskan oleh Teori Keagenan. Teori ini menjelaskan bahwa pemerintah sebagai agent memiliki kewajiban untuk memenuhi kebutuhan rakyat sebagai principal yang diwakilan oleh DPRD dalam menghasilkan laporan keuangan yang berkualitas dan akuntabel agar memudahkan principal dalam mengambil keputusan. Dengan memanfaatkan teknologi informasi secara efektif dan efisien akan memudahkan pemerintah daerah untuk menghasilkan laporan keuangan yang berkualitas dan tepat waktu. Penelitian ini sejalan dengan penelitian Tawaqal dan Suparno (2017), Wardani dan Nugroho (2018), Oktavia dan Rahayu (2019) serta Hasanah, dkk. (2019). 


\section{Pengaruh Sistem Pengendalian Intern Terhadap Kualitas Laporan Keuangan Pemerintah}

\section{Daerah}

Berdasarkan uji parsial t pada hipotesis ketiga, telah didapat nilai t tabel adalah 1,994, $\mathrm{t}$ hitung adalah 3,090 dan signifikansinya 0,003. Ketentuan dari uji parsial $\mathrm{t}$ ini adalah jika $\mathrm{t}$ hitung $<\mathrm{t}$ tabel maka $\mathrm{H}_{3}$ diterima dan $\mathrm{Ha}_{3}$ ditolak begitu juga sebaliknya, jika $\mathrm{H}_{3}$ ditolak dan $\mathrm{Ha}_{3}$ diterima, maka nilai signifikansinya harus $<0,05$. Dari hasil uji t hipotesis pertama didapat $\mathrm{t}$ hitung $>\mathrm{t}$ tabel yaitu 3,090 $>1,994$ dengan nilai sig.t $0,003<0,05$. Dari penjelasan di atas, dapat disimpulkan bahwa hasil dari uji t hipotesis ketiga adalah Sistem Pengendalian Intern berpengaruh signifikan terhadap Kualitas Laporan Keuangan Pemerintah Daerah.

Berdasarkan data yang diperoleh, diketahui penerapan sistem pengendalian intern di bagian keuangan tiap OPD Pemerintah Kota Pekanbaru dapat dikatakan baik. Semakin baik sistem pengendalian intern yang diterapkan maka semakin berkualitas laporan keuangan yang dihasilkan. Hubungan antara sistem pengendalian intern dan kualitas laporan keuangan dapat dijelaskan oleh Teori Keagenan. Teori ini menjelaskan bahwa pemerintah daerah sebagai agent diwajibkan memenuhi kebutuhan rakyat sebagai principal yang diwakilkan oleh DPRD dalam menghasilkan laporan keuangan yang berkualitas dan akuntabel agar memudahkan principal dalam mengambil keputusan. Penerapan sistem pengendalian intern dapat membantu pemerintah daerah dalam meminimalisir kelemahan dan temuan dalam laporan keuangan sehingga laporan keuangan yang dihasilkan berkualitas. Penelitian ini sejalan dengan penelitian Indriasih (2014), Karsana dan Suaryana (2017), Muhammad (2019) serta Herawati (2014).

\section{SIMPULAN}

Hasil dari penelitian ini dapat disimpulkan bahwa seluruh variabel independen, yaitu Kompetensi Sumber Daya Manusia, Pemanfaatan Teknologi Informasi dan Sistem Pengendalian Intern berpengaruh signifikan terhadap Kualitas Laporan Keuangan Pemerintah Daerah di OPD Pemerintah Kota Pekanbaru.

Keterbatasan dalam penelitian ini yaitu; (a) hanya beberapa responden yang bisa ditemui secara langsung untuk dilakukannya wawancara; (b) penelitian ini hanya menggunakan tiga pengaruh variabel independen terhadap variabel dependen; dan (c) terdapat kuesioner yang tidak direspon oleh responden, dikarenakan lamanya birokrasi penyampaian kuesioner ke responden yang bersangkutan dari rentang waktu yang ditentukan, sehingga tingkat pengembalian kuesioner tidak $100 \%$.

Saran untuk menutupi keterbatasan penelitian ini untuk peneliti selanjutnya adalah 
dengan menambahkan wawancara untuk melengkapi metode penelitian sehingga hasil yang didapat lebih baik; dapat menambahkan variabel independen maupun intervening/moderating yang diketahui dapat mempengaruhi kualitas laporan keuangan pemerintah daerah; dan diharapkan untuk dapat memperoleh data secara keseluruhan dari semua sampel yang telah ditetapkan, agar hasil yang diperoleh maksimal.

Implikasi dari penelitian ini bagi Pemerintah Kota Pekanbaru yaitu, diharapkan hasil penelitian ini dapat menjadi bahan evaluasi dan pertimbangan untuk OPD di Pemerintah Kota Pekanbaru dalam proses penyusunan laporan keuangan agar dapat tercapai kualitas laporan keuangan yang baik, yang mana dapat meminimalisir kelemahan dan temuan BPK dalam laporan keuangan yang akan diaudit. Serta bagi peneliti selanjutnya, diharapkan penelitian ini dapat menjadi jurnal acuan yang digunakan untuk meneliti kembali topik yang sama.

\section{REFERENSI}

Evicahyani, S. I., \& Setiawina, N. D. (2016). Analisis Faktor-Faktor yang Mempengaruhi Kualitas Laporan Keuangan Pemerintah Daerah Kabupaten Tabanan. E-Jurnal. Ekonomi dan Bisnis Universitas Udayana.

Faristina, R. (2011). Faktor-Faktor yang Mempengaruhi Keandalan dan Timeliness Pelaporan Keuangan. Skripsi. Universitas Diponegoro.

Hasanah, Y. A., Sasongko, N., \& Bawono, A. D. B. (2019). Pengaruh Pemahaman Akuntansi, Penerapan Sistem Akuntansi Keuangan Daerah, Peran Internal Audit, dan Penerapan Standar Akuntansi Pemerintah terhadap Kualitas Laporan Keuangan Pemerintah Daerah (Studi pada SKPD di Pemerintah Kabupaten Sukoharjo). The 9th URECOL.

Herawati, T. (2014). Pengaruh Sistem Pengendalian Intern terhadap Kualitas Laporan Keuangan (Survei pada Organisasi Perangkat Daerah Pemda Cianjur). STAR - Study \& Accounting Research, 1-14.

Indriasih, D. (2014). The Effect of Government Apparatus Competence and the Effectiveness of Government Internal Control Toward the Quality of Financial Reporting in Local Government. Research Journal of Finance and Accounting, 38-47.

Karsana, I. W., \& I Gusti N. A. S. (2017). Pengaruh Efektivitas Penerapan SAP, Kompetensi SDM, dan SPI pada Kualitas Laporan Keuangan Pemerintah Kabupaten Bangli. EJurnal Akuntansi. Universitas Udayana.

Muhammad, F. A. (2019). Diterapkannya Sistem Akuntansi dan Sistem Pengendalian Intern untuk Mempengaruhi Kualitas Laporan Keuangan. Syntax Idea.

Nurillah, A. (2014). Pengaruh Kompetensi Sumber Daya Manusia, Penerapan Sistem 
Akuntansi Keuangan Daerah (SAKD), Pemanfaatan Teknologi Informasi, dan Sistem Pengendalian Intern Terhadap Kualitas Laporan Keuangan Pemerintah Daerah (Studi Empiris pada SKPD Kota Depok). Skripsi. Universitas Diponegoro.

Oktavia, S., \& Rahayu, S. (2019). Pengaruh Kompetensi Sumber Daya Manusia, Komitmen Organisasi dan Sistem Akuntansi Keuangan Daerah terhadap Kualitas Laporan Keuangan Daerah (Studi Kasus pada Satuan Kinerja Perangkat Daerah Kota Bandung Tahun 2018), e-Proceeding of Management, 652-659.

Sholohah, S. A., \& Sulistyawati. (2018). Kualitas Laporan Keuangan dan Faktor-Faktor yang Mempengaruhinya (Studi Kasus pada DPKAD Kota Semarang). FOKUS EKONOMI Jurnal Ilmiah Ekonomi, 280-300.

Tawaqal, Irzal, \& Suparno. (2017). Pengaruh Penerapan Sistem Informasi Akuntansi, Sistem Pengendalian Internal, dan Kompetensi Sumber Daya Manusia terhadap Kualitas Laporan Keuangan Satuan Kerja Perangkat Daerah di Pemerintah Kota Banda Aceh. JIMEKA, 125-135.

Wardani, D. K., \& Nugroho, S. P. (2018). The Impact of Information Technology on Financial Statement Quality: A Moderating Role of Internal Control System. ICASI, $10-15$.

Wawo, A. B., Idrus, M. S., Rahayu, M., \& Djumahir (2013). The Influence of Internal and External Monitoring, Leadership Style and Good Public Governance Implementation on Financial Reporting Performance (Study on SKPDs/Local Government Task Forces at South-East Sulawesi Province). J, Basic. Appl. Sci. Res, 402-412.

$\underline{\text { http://pekanbaru.bpk.go.id }}$

https://www.bpk.go.id/

https://www.cakaplah.com 